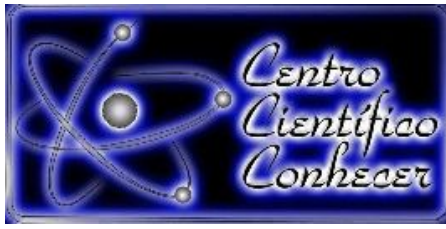

\title{
AVALIAÇÃO DA QUALIDADE MICROBIOLÓGICA DE QUEIJOS ARTESANAIS TIPO MINAS FRESCAL EM BARRA DO BUGRES - MT
}

Valeska Morgana Corrêa Bastistella ${ }^{1 *}$, Karolay Amancia de Jesus Fernandes ${ }^{1}$, Aline Pedrosa de Oliveira ${ }^{2}$, Fábio Cristiano Angonesi Brod ${ }^{2}$

${ }^{1}$ Bacharéis em Engenharia de Alimentos - Universidade do Estado de Mato Grosso (UNEMAT)

${ }^{2}$ Docentes do curso de Engenharia de Alimentos - Universidade do Estado de Mato Grosso (UNEMAT)

*E-mail principal: valeska_morgana@hotmail.com

Recebido em: 02/06/2019 - Aprovado em: 15/06/2019 - Publicado em: 22/07/2019 DOI: 10.18677/Agrarian_Academy_2019a40

\section{RESUMO}

O Queijo Minas Frescal é classificado como semi-gordo, de alta umidade e de massa crua, obtido por coagulação enzimática do leite com coalho ou com a ação de bactérias lácticas especificas. Quando se trata de produtos manuseados, principalmente queijos, a preocupação é grande em relação à contaminação por Salmonella sp., Listeria monocytogenes, coliformes totais e termotolerantes. A ocorrência de doenças e de processos de deterioração indesejáveis reforçam a necessidade de se realizar controle sobre a qualidade dos alimentos de origem animal. Assim, o presente estudo objetivou avaliar o queijo Minas Frescal oriundo de diferentes estabelecimentos na cidade de Barra do Bugres - MT, a fim de verificar a qualidade microbiológica dos produtos comercializados. As análises de coliformes totais e termotolerantes foram realizadas de acordo com o preconizado pela IN62 do MAPA. As análises de Salmonella sp. e Listeria monocytogenes foram realizadas por Reação de Cadeia Polimerase (PCR). Foram analisadas 18 amostras de queijos Minas Frescal artesanais oriundos de estabelecimentos comerciais locais. Todas as amostras apresentaram contaminação por coliformes totais e termotolerantes, cinco amostras (27,78\%) apresentaram contaminação maior que $1,1 \times 103 \mathrm{NPM} / \mathrm{g}$ para coliformes totais e três amostras (16,67\%) maior que $1,1 \times 103 \mathrm{NMP} / \mathrm{g}$ para coliformes termotolerantes. Os resultados para Salmonella sp. e Listeria monocytogenes foram negativos para todas as amostras. Concluindo assim, que 100\% das amostras estavam livres de patógenos de acordo com as análises realizadas.

PALAVRAS-CHAVE: Controle da Qualidade; Coliforme totais e termotolerantes, PCR. 


\title{
MICROBIOLOGICAL QUALITY EVALUATION OF MINAS FRESH CHEESE IN BARRA DO BUGRES - MT
}

\begin{abstract}
ABSCTRACT
Minas Frescal cheese is classified as semi-fat, high moisture and raw dough, obtained by enzymatic coagulation of milk with rennet or with the action of specific lactic bacteria. When it comes to handled products, mainly cheeses, the concern is great regarding the contamination by Salmonella sp., Listeria monocytogenes, total coliforms and thermotolerantes. The occurrence of undesirable diseases and deterioration processes reinforces the need to control the quality of food of animal origin. Thus, the present study aimed to evaluate the Minas Frescal cheese from different establishments in the city of Barra do Bugres - MT, in order to verify the microbiological quality of the products sold. The analyzes of total and thermotolerant coliforms were performed according to the one recommended by the IN62 of the MAPA. The Salmonella sp. and Listeria monocytogenes were performed by Chain Reaction Polymerase (PCR). Was analyzed 18 samples of Minas Frescal handmade cheese from local commercial establishments. All samples presented contamination by total coliforms and thermotolerant coliforms, five samples $(27.78 \%)$ presented contamination higher than $1.1 \times 103 \mathrm{NPM} / \mathrm{g}$ for total coliforms and three samples (16.67\%) greater than $1.1 \times 103$ MPN / $g$ for thermotolerant coliforms. The results for Salmonella sp. and Listeria monocytogenes were negative for all samples. In conclusion, $100 \%$ of the samples were free of pathogens according to the analyzes.
\end{abstract}

KEYWORDS: Quality control; PCR; Total coliform and thermotolerant.

\section{INTRODUÇÃO}

Queijo Minas Frescal é classificado como semi-gordo, de alta umidade e de massa crua, obtido por coagulação enzimática do leite com coalho ou com a ação de bactérias lácticas especificas (BRASIL, 1996). O leite utilizado para fabricação de queijos deve ser submetido à pasteurização (BRASIL, 1996), no entanto, quando produzido artesanalmente, geralmente é utilizado leite cru, o que aumenta as chances de proliferação de bactérias patogênicas (FEITOSA et al., 2003).

O padrão microbiológico é um critério rigoroso a ser considerado em alimentos, sendo considerados impróprios para consumo aqueles com presença de patógenos ou que apresentem nível de contaminação maior do que o estabelecido por legislação específica. Quando se trata de produtos manuseados, principalmente queijos, a preocupação é grande em relação à contaminação por Samonella sp., Listeria monocytogenes e coliformes totais e termotolerantes. O grupo de bactérias coliformes são os principais contaminantes relacionados à deterioração de queijos, acarretando em fermentações indesejadas (PINTO, et al., 2011). Quanto à Salmonela, sabe-se que esta permanece viável em queijos contaminados por longo período de tempo, causando infecções alimentares que provocam diarreia, febre e dores abdominais (FEITOSA et al., 2003).

A Listeria monocytogenes pode ser introduzida no queijo Minas Frescal artesanal pela utilização de leite cru para a fabricação. Este microrganismo possui resistência a temperaturas de refrigeração, o que dificulta o controle, e sua presença nos alimentos pode causar doenças graves como meningite e osteomielite (BARANCELLI, 2011).

A ocorrência de doenças e de processos de deterioração indesejáveis reforçam a necessidade de realizar controle sobre a qualidade dos alimentos de 
origem animal, cabendo aos serviços de inspeção a realização desta tarefa. No entanto, produtos artesanais ou clandestinos não passam por uma vigilância que possa garantir a qualidade destes alimentos, possibilitando assim a ocorrência de infecção e intoxicações alimentares (FEITOSA et al., 2003).

Dessa forma, o presente estudo objetivou avaliar a qualidade microbiológica de amostras de queijo Minas Frescal oriundos de diferentes estabelecimentos na cidade de Barra do Bugres - MT, a fim de verificar a presença de Salmonella sp., Listeria Monocytogenes, utilizando a técnica de Reação em Cadeia da Polimerase (PCR), e coliformes totais e termotolerantes pela técnica de tubos múltiplos.

\section{MATERIAL E MÉTODOS}

Para avaliar a qualidade microbiológica dos queijos artesanais tipo Minas Frescal produzidos no município de Barra do Bugres, foram coletados queijos comercializados em dois supermercados e uma feira-livre locais. As coletas foram realizadas no mês de abril de 2018, uma vez por semana, durante três semanas, sendo obtidas seis amostras por coleta em cada ponto, totalizando 18 amostras.

Os estabelecimentos foram selecionados baseados na distribuição dos queijos por parte dos produtores locais. A escolha das amostras para as análises foi de forma aleatória e após cada coleta as amostras foram devidamente identificadas e transportadas em caixas de material isotérmico (isopor), contendo placas de gelo e mantidas sob refrigeração até o momento das análises.

As análises microbiológicas foram realizadas no Laboratório de Microbiologia da Universidade do Estado de Mato Grosso, Campus de Barra do Bugres-MT.

\section{Preparo das amostras}

As embalagens dos queijos coletados foram sanitizadas externamente com álcool $70 \%$ e posteriormente retiradas. Em seguida, os queijos foram triturados e homogeneizados com o auxílio de utensílios previamente esterilizados. Após o processo de homogeneização foram separadas alíquotas de $1 \mathrm{~g}$ e adicionadas em tubos contendo $9 \mathrm{~mL}$ de água peptonada tamponada a $1 \%$.

\section{Análise de coliformes totais e termotolerantes}

As análises de coliformes totais e termotolerantes foram realizadas de acordo com o preconizado pela Instrução Normativa $n^{\circ}$ 62, de 26 de agosto de 2003, do Ministério da Agricultura, Pecuária e Abastecimento (BRASIL, 2003).

Para determinação (NMP) de coliformes totais e termotolerantes, foram realizadas três diluições da amostra $\left(10^{-1}, 10^{-2}, 10^{-3}\right)$ em água peptonada, e em seguida, transferiu-se $1 \mathrm{~mL}$ de cada diluição para tubos de ensaio contendo caldo Lauril Sulfato Triptose (LST) e tubos de Duhran invertidos para observar a produção de gás, sendo esta etapa considerada presuntiva para presença de coliformes.

Os tubos foram incubados a uma temperatura de $35 \stackrel{\circ}{\circ}$ por 48 horas, após o período de incubação foram verificados os tubos que apresentaram produção de gás e turvação do meio, sendo estes considerados positivos na etapa presuntiva.

Os tubos positivos foram então repicados para tubos contendo $10 \mathrm{~mL}$ de caldo verde brilhante bile $2 \%$ de lactose e então incubados a $35^{\circ} \mathrm{C}$ por 24 horas para a verificação da presença de coliformes totais. Também foram repicados para tubos contendo $10 \mathrm{~mL}$ de caldo $\mathrm{EC}$ e incubados a $45^{\circ} \mathrm{C}$ por 24 horas para a detecção de coliformes termotolerantes. 
Após o período de incubação, os tubos contendo caldo Verde Brilhante e caldo EC que produziram gás foram considerados positivos e então comparados à Tabela de Hoskin e os resultados registrados como NMP/g de Coliformes Totais e Termotolerantes.

Pesquisa por Salmonella sp.

Os tubos contendo água peptonada com um grama de amostra foram incubados a $37^{\circ} \mathrm{C}$ por 24 horas e, em seguida, alíquotas de $1 \mathrm{~mL}$ foram transferidas para tubos contendo $9 \mathrm{~mL}$ de caldo Rappaport Vasiliadis (RV) e incubado a $37{ }^{\circ} \mathrm{C}$ por 24 horas. Após o período de encubação $2 \mathrm{~mL}$ de cada amostra em caldo RV foram transferidos para micro tubos e congelados para posterior extração de DNA.

Pesquisa por Listeria monocytogenes

Os tubos contendo água peptonada e um grama de amostra foram incubados a $37^{\circ} \mathrm{C}$ por 24 horas. Após o período de encubação $2 \mathrm{~mL}$ de água peptonada foram transferidos para microtubos e congelados para posterior extração do DNA.

\section{Extração do DNA}

A extração de DNA foi realizada de acordo com Protocolo determinado pelo fabricante do kit para extração de DNA genômico (LGC Biotecnologia). O kit de extração continha tubos com tampão de lise e resina Brasílica (L1), tampões de lavagem (L2, L3 e L4) e quatro tubos contendo tampão de eluição (E1).

A extração do DNA das amostras iniciou-se com a homogeneização dos tubos contendo tampão L1 por 10 segundos no vórtex, em seguida adicionou-se 100 $L$ de amostra nos tubos L1 e agitou-se novamente no vórtex por 10 segundos para homogeneizar as amostras com o tampão de lavagem L1. O processo de homogeneização foi repetido durante 10 minutos, agitando cada tubo periodicamente a cada 1 minuto e, por fim, vortexando por mais 10 segundos e centrifugados a $10.000 \mathrm{rpm}$ durante 30 segundos. O sobrenadante foi descartado tomando cuidado para não perturbar o precipitado.

Os precipitados foram dissolvidos em 900 L do tampão de lavagem L2 e centrifugados a $10.000 \mathrm{rpm}$ por 30 segundos, posteriormente descartou-se o sobrenadante sem remover o precipitado e, mais uma vez, foram adicionados 900 $\mathrm{L}$ do tampão de lavagem $\mathrm{L} 2$, repetindo o processo de dissolução do precipitado e de centrifugação.

O sobrenadante foi descartado para que o precipitado fosse lavado pelo tampão de lavagem L3, em que se repetiu os mesmos passos do tampão de lavagem L2 e em seguida os precipitados foram lavados com o tampão de lavagem L4 seguindo o mesmo procedimento.

Após a etapa de lavagem L4 os tubos contendo os precipitados foram aquecidos em estufa a $56 \stackrel{\circ}{\circ} \mathrm{C}$ por 10 minutos com as tampas abertas, em seguida foram adicionados $100 \mathrm{~L}$ do tampão de eluição $\mathrm{E} 1$ aos precipitados $\mathrm{e}$ homogeneizados com a ajuda do vórtex.

Ao término da homogeneização os tubos foram novamente colocados em estufa a $56^{\circ} \mathrm{C}$ por 10 minutos com suas tampas fechadas, e por fim foram centrifugados a $12.000 \mathrm{rpm}$ durante 10 minutos e os sobrenadantes contendo os ácidos nucleicos extraídos foram transferidos para novos tubos e congelados a -20 oC até o momento da amplificação por PCR convencional. 
Ensaio de PCR para detecção de Salmonella sp. e Listeria monocytogenes

\section{Amplificação}

A detecção de Salmonella sp. e Listeria monocytogenes foi realizada por PCR convencional. Os iniciadores utilizados estão dispostos no Quadro 1.

QUADRO 1. Gene para Identificação de Salmonella sp. e Listeria monocytogenes Iniciadores e Tamanho do Produto da PCR (amplicon) em Pares de Bases (pb)

\begin{tabular}{|c|c|c|c|}
\hline Gene & Iniciador & $\begin{array}{l}\text { Pares } \\
\text { de } \\
\text { Bases }\end{array}$ & Referência \\
\hline \multirow{2}{*}{$\begin{array}{c}\text { inv A } \\
\text { (Salmonella sp.) }\end{array}$} & $\begin{array}{c}\text { Senso }-5^{\prime}- \\
\text { GTGAAATTATCGCCACGTTCGGGCAA - } \\
\text { 3' }\end{array}$ & \multirow[t]{2}{*}{284} & \multirow{2}{*}{$\begin{array}{l}\text { Rahn et al; } \\
1992\end{array}$} \\
\hline & $\begin{array}{c}\text { Antissenso - 5'- } \\
\text { TCATCGCACCGTCAAAGGAACC -3' }\end{array}$ & & \\
\hline \multirow{2}{*}{$\begin{array}{c}\operatorname{PrTA}(L . \\
\text { monocytogenes })\end{array}$} & $\begin{array}{c}\text { Senso - 5'- } \\
\text { GATACAGAAACATCGGTTGGC-3' }\end{array}$ & \multirow{2}{*}{274} & \multirow{2}{*}{$\begin{array}{l}\text { D'Agostino } \\
\text { et al; } 2004\end{array}$} \\
\hline & $\begin{array}{c}\text { Antissenso - 5'- } \\
\text { GTGTAATCTTGATGCCATCAGG-3' }\end{array}$ & & \\
\hline
\end{tabular}

A amplificação e eletroforese para detecção de Salmonella sp. seguiram o protocolo descrito por Rahn et al. (1992). Os iniciadores foram utilizados em uma reação de $20 \mathrm{~L}$, contendo $10 \mathrm{~L}$ de PCR Master-Mix (LGC Biotecnologia), $1 \mathrm{M}$ de cada primer, 7,2 $L$ de água livre de nuclease e $2 L$ de DNA amostral. A reação de amplificação foi realizada no termociclador (Amplitherm Termal Cycler tx).

Para amplificação do DNA foram utilizados quatro passos (condições de ciclos), uma incubação inicial a $72 \stackrel{\circ}{\circ}$ por sete minutos, seguidos por 35 ciclos de desnaturação a $94 \stackrel{\circ}{\circ} \mathrm{C}$ por um minuto; anelamento dos iniciadores a $53 \stackrel{\circ}{\circ}$ por 2 minutos; extensão a $72 \stackrel{\circ}{\circ}$ por três minutos, seguindo de um último ciclo que será uma incubação de $72 \stackrel{\circ}{\circ} \mathrm{C}$ por sete minutos. Um controle positivo e um controle negativo foram utilizados para a verificação da reação. Ao final da amplificação as reações foram congeladas até o momento da eletroforese. A amplificação para detecção de Listeria Monocytogenes seguiu o protocolo descrito por D Agostino et al (2004) com algumas modificações relacionadas ao volume utilizado na reação.

A amplificação foi realizada no termociclador (Amplitherm termal Cyclers tx25) utilizando uma reação de $25 \mathrm{~L}$, contendo $10 \mathrm{~L}$ de PCR master-mix (LGC Biotecnologia), 0,4 $L$ de cada primer $(0,2 \mathrm{M}), 9,2 \mathrm{~L}$ de água livre de nuclease $e$ $5 \mathrm{~L}$ de DNA amostral. O programa de ciclos de amplificação consistiu em uma incubação inicial a $94{ }^{\circ} \mathrm{C}$ por 3 minutos, seguidos de 40 ciclos de desnaturação a 94 ㄷ por 40 segundos, anelamento dos iniciadores a $55 \stackrel{\circ}{ } \mathrm{C}$ por 45 segundos, extensão a $74 \stackrel{\circ}{\circ}$ por 1 minuto e 15 segundos e uma extensão final a $74 \stackrel{\circ}{\circ} \mathrm{C}$ por 7 minutos. Ao final da amplificação as reações foram congeladas até o momento da eletroforese. 


\section{Eletroforese}

Uma alíquota de $5 \mathrm{~L}$ da reação foi utilizada para realização da eletroforese em gel de agarose a $2 \%$ em TBE $1 \mathrm{X}$, a 110 volts, contendo $1,5 \mathrm{~L}$ do corante Safer Dye (Kasvi). Um marcador de 50 pb foi utilizado para comparação com peso molecular dos amplicon alvo.

Tratamento estatístico

Os resultados foram analisados utilizando estatística descritiva.

\section{RESULTADOS E DISCUSSÃO}

\section{Coliformes totais e termotolerantes}

Foram analisadas 18 amostras de queijos Minas Frescal artesanais oriundos de estabelecimentos comerciais localizados na cidade de Barra do Bugres - MT, para avaliação de Número Mais Provável de coliformes totais e termotolerantes. Os resultados das análises podem ser observados na Tabela 1.

TABELA 1. Número Mais Provável de Coliformes Totais e Termotolerantes por Grama de Queijos Minas Frescal Artesanais, Coletados na Cidade de Barra do Bugres-MT no Mês de Abril de 2018

\begin{tabular}{cccc}
\hline Microrganismos & NMP/g & $\begin{array}{c}\mathbf{N}^{\circ} \text { de } \\
\text { amostras }\end{array}$ & $\begin{array}{c}\text { (\%) de } \\
\text { amostras }\end{array}$ \\
\hline Coliformes Totais & $10^{3}<x<1,1 \times 10^{3}$ & 10 & 55,56 \\
& $>1,1 \times 10^{3}$ & 5 & 16,67 \\
Coliformes & $<10^{3}$ & 8 & 27,78 \\
Termotolerantes & $10^{3}<x<1,1 \times 10^{3}$ & 7 & 44,44 \\
& $>1,1 \times 10^{3}$ & 3 & 38,89 \\
\hline
\end{tabular}

Todas as amostras apresentaram contaminação por coliformes totais e termotolerantes. Conforme pode ser visualizado na Tabela 1, dez (55,5\%) das amostras apresentaram contagem de bactérias abaixo de $10^{3} \mathrm{NPM} / \mathrm{g}$ para coliformes totais. Outras três (16,67\%) tiveram a contagem de bactérias maior que $103 \mathrm{NPM} / \mathrm{g}$ e menor que $1,1 \times 10^{3} \mathrm{NPM} / \mathrm{g}$ e cinco amostras (27,78\%) apresentaram contaminação maior que $1,1 \times 10^{3} \mathrm{NPM} / \mathrm{g}$ para coliformes totais.

Resultados superiores foram encontrados por Oliveira e colaboradores (2017), ao avaliarem a presença de coliformes totais e termotolerantes em queijos Minas Frescal produzidos na região de Londrina - Paraná. Os pesquisadores observaram ainda que $55,6 \%$ das amostras apresentaram contagem para coliformes totais superior a 1,0x103 NMP/g. Dias e colaboradores (2016), também encontraram contagem de coliformes totais superiores aos resultados do presente estudo, com média de 3,1×104 NMP/g em queijos Minas Frescal artesanais produzidos na região Sul de Goiás. Na região Sudoeste da Bahia, Mottin e pesquisadores (2016), reportaram contagens de coliformes totais maiores de $103 \mathrm{NMP} / \mathrm{g}$ para queijos Minas Frescal.

AGRARIAN ACADEMY, Centro Científico Conhecer - Goiânia, v.6, n.11; p. 4052019 
Considerando os resultados para coliformes termotolerantes, oito amostras $(44,44 \%)$ apresentaram contaminação menor que $103 \mathrm{NPM} / \mathrm{g}$, sete amostras $(38,89 \%)$ obtiveram contagem maior que $10^{3}$ e menor que $1,1 \times 10^{3} \mathrm{NPM} / \mathrm{g}$ e três amostras (16,67\%) maior que $1,1 \times 10^{3} \mathrm{NMP} / \mathrm{g}$.

Oliveira e autores (2017), encontraram resultados inferiores para microrganismos termotolerantes, em $72,29 \%$ das amostras, estas apresentaram contagem inferior a $1,0 \times 10^{2} \mathrm{NMP} / \mathrm{g}$. Dias et al., (2017) também encontraram resultados inferiores aos apresentados na Tabela 1, tendo encontrado $60 \%$ das amostras com contagem abaixo de $103 \mathrm{NMP} / \mathrm{g}$. Porém, Mottin e colaboradores (2016), encontram resultados superiores, $100 \%$ das amostras com contagem acima de 103 NMP/g de queijos Minas Frescal na região Sudoeste da Bahia.

Apesar do presente trabalho ter apresentado contagem para coliformes termotolerantes superior ao encontrado pela maioria dos autores citados, este apresentou resultados inferiores de coliformes totais e considerando os padrões estabelecidos pela ANVISA, conforme Resolução RDC $n^{\circ} 12$ de 02 de Janeiro de 2001 (BRASIL, 2001), pode-se afirmar que os queijos analisados apresentaram boas condições de higiene, uma vez que, $55,56 \%$ e $44,44 \%$ das amostras apresentaram contagem menor que $10^{3} \mathrm{NMP} / \mathrm{g}$ para coliformes totais e termotolerantes, respectivamente.

Os microrganismos pertencentes ao grupo coliformes são considerados indicadores. É importante ressaltar que este grupo de bactérias tem como habitat natural o trato intestinal do homem e de outros animais de sangue quente e o fato de estarem presentes nos queijos é indicativo da ausência de cuidados higiênicosanitários e boas práticas de manipulação. A presença destes microrganismos pode ser considerada um indicativo de contaminação de origem fecal, demonstrando riscos à saúde dos consumidores, pois podem estar associadas a microrganismos patogênicos (SALOTTI et al., 2006; PIETROWSKI et al., 2008; KOUSTA et al., 2010; OLIVEIRA et al., 2017).

\section{Salmonella Sp. e Listeria monocytogenes}

As pesquisas de Samonella sp. e Listeria monocytogenes foram realizadas aplicando a técnica de PCR convencional, utilizando controles positivos e negativos para confiabilidade dos resultados. Foram analisadas 18 amostras de queijos Minas Frescal, coletados em estabelecimentos comerciais localizados na cidade de Barra do Bugres - MT. Os resultados estão expressos na Tabela 2.

TABELA 2. Resultados das Análises de Salmonella sp e Listeria monocytogenes por Quantidade Total de Amostras

\begin{tabular}{ccc}
\hline & $\begin{array}{c}\text { Total de amostras } \\
\text { positivas/ amostras } \\
\text { avaliadas }\end{array}$ & $\begin{array}{c}\% \text { de amostras } \\
\text { positivas }\end{array}$ \\
\hline Salmonella sp. & $0 / 18$ & 0 \\
Listeria monocytogenes & $0 / 18$ & 0 \\
\hline
\end{tabular}

Conforme Tabela 2, os resultados para Salmonella sp. e Listeria monocytogenes foram negativos para todas as amostras, ou seja, $100 \%$ das amostras estavam livres dos patógenos analisados. Resultados semelhantes foram 
encontrados por Dias e colaboradores (2016) que, ao analisarem queijos Minas Frescal artesanais, não encontraram Salmonella sp., em amostras coletadas na cidade de Morrinhos - GO. Ainda, Valiatti e colaboradores (2015), ao analisarem quatro amostras de queijos Minas Frescal artesanais no município de Ji-Paraná, observaram ausência de Salmonella sp.

Em relação à Listeria monocytogenes, Salotti e colaboradores (2006), ao analisarem um total de 30 amostras de queijos Minas Frescal artesanais obtidos no município de Jaboticabal - SP também não observaram a presença do patógeno. Por outro lado, Vinha e pesquisadores (2016), analisaram 39 amostras de queijos Minas Frescal comercializados informalmente no município de Viçosa - MG e uma amostra estava contaminada por Listeria monocytogenes.

A ausência de Salmonella sp. e Listeria monocytogenes nas amostras demonstram que apesar de serem produzidas artesanalmente estão de acordo com a Legislação vigente e então apropriados para o consumo.

\section{CONCLUSÕES}

De acordo com os resultados obtidos no presente estudo, conclui-se que a contagem de coliformes totais e termotolerantes apresentaram-se dentro dos padrões estabelecidos pela RDC 12 de 2001.

Para todas as amostras analisadas, não foi observada a presença de Salmonella sp. e Listeria monocytogenes, portanto, as amostras estão em boas condições, adequadas para o consumo humano. 


\section{REFERÊNCIAS}

BARANCELLI, G.V.; SILVA-CRUZ, J.V.; OLIVEIRA, C. A. F. Listeria monocytogenes: Ocorrência em produtos lácteos e suas implicações em saúde pública. Arquivo do Instituto Biológico, v.78, n.1, p.155-168, 2011.

BRASIL. Agência Nacional de Vigilância Sanitária. Resolução CNNPA no 12 de 2001.

BRASIL. Ministério da Agricultura, Pecuária e Abastecimento. Instrução Normativa № 62, de 26 de Agosto de 2003.

BRASIL. Ministério da Agricultura. Portaria no 146, de 07/03/1996. 38 B.CEPPA, Curitiba, v.21, n.1, 2003. Regulamento técnico de identidade e qualidade de queijos. Diário Oficial da República Federativa do Brasil, Brasília, p.3977-3978, 1996.

D' AGOSTINO, M.; WAGNER, J. A.; VAZQUEZ-BOLAND.; KUTCHTA, T.; KARPISKOVA, J.; et al., Um método validado baseado em PCR para detectar Listeria monocytogenes Usando leite cru como um modelo alimentar rumo a um padrão internacional. Jornal de Proteção de Alimentos, v.67, n.8, p.1646-1655, 2004

DIAS, B. F.; FERREIRA, S. M.; CARVALHO, V. S.; SOARES, D. S. B. Qualidade microbiológica e físico-química de queijo minas frescal artesanal e industrial. Revista de Agricultura Neotropical, Cassilândia-MS, v. 3, n. 3, p. 57-64, 2016.

FEITOSA, T.; BORGES, M. D. F.; NASSU, R. T.; AZEVEDO, E. D. F.; MUNIZ, C. R. Pesquisa de Salmonella $s p$., listeria $s p$. e microrganismos indicadores higiênicosanitários em queijos produzidos no estado do Rio Grande do Norte. Ciência e Tecnologia de Alimentos, Campinas, v.23, n.3, p.162-165, 2003.

KOUSTA, M.; MATARAGAS, M.; SKANDAMIS, P.; DROSINOS, E. H. Prevalence and sources of cheese contamination with pathogens at farm and processing levels. Food Control Journal, v.21, n.6, p.805-815, 2010.

MOTTIN, V. D.; SILVA, L. L.; ROCHA, J. N.; TEIXEIRA NETO, M. R. Quantificação e correlações de parâmetros microbiológicos em queijos minas frescal no sudoeste da Bahia. Arquivos de Ciências Veterinárias e Zoologia da UNIPAR, Umuarama, v.19, n.3, p.137-142, 2016.

OLIVEIRA, M. A.; KURIHARA, Y. R.; SILVA, F. F.; SILVA, G. F.; JUNIOR, R. C. J.; BELOTI, V. Condições higiênico-sanitárias da produção de queijos tipo Mussarela e 
Minas Frescal comercializados no norte do Paraná, Brasil. Revista Instituto Laticínios Cândido Tostes, Juiz de Fora - MG, v.72, n.1, p.40-47, 2017.

PIETROWSKI, G. A. M.; RANTHUM, M.; CROZETA, T.; JONGE, V. de. Avaliação da qualidade microbiológica de queijo tipo Mussarela comercializado na cidade de Ponta Grossa, Paraná. Revista Brasileira de Tecnologia Agroindustrial, v.02, n.2, p.25-31, 2008.

PINTO, F. G. S.; SOUZA, M.; SALING, S.; MOURA, A. C. Qualidade microbiológica de queijo Minas Frescal comercializado no município de Santa Helena, PR, Brasil. Arquivo do Instituto Biológico, v.78, n.2, p.191-198, 2011.

RAHN, K.; DE GRANDIS, S.A; CLARKE, R. C.; McEWEN, S. A.; GALÁN, J. E.; GINOCCHIO, C.; CURTIS III, R.; GYLES, C. L. Amplificação de uma sequência do gene invA de Salmonella typhimurium pela reação em cadeia da polimerase como um método de detecção de Salmonella. Sondas Moleculares e Celulares, p.271279, 1992.

SALOTTI, B. M.; CARVALHO, A. C. F. B.; AMARAL, L. A.; VIDAL-MARTINS, A. M. C.; CORTEZ, A. L. Qualidade microbiológica do queijo Minas Frescal comercializado no município de Jaboticabal, SP, Brasil. Arquivos do Instituto Biológico, São Paulo, v.73, n.2, p.171-175, 2006.

VALIATTI, T. B.; SOBRAL, F. de O. S.; ROMÃO, N. F.; MALAVASI, N. V. Avaliação das condições higiênico sanitárias de queijos tipo Minas Frescal comercializados em feiras no município Ji - Paraná-Ro. Revista Científica da Faculdade de Educação e Meio Ambiente. v.6, n.1: p.59-68, 2015.

VINHA, M. B.; PINTO, C. L. O.; VANETTI, M. C. D.; SOUZA, M. R. M.; CHAVES, J. B. P. Qualidade de queijos Minas Frescal produzidos e comercializados informalmente em agroindústrias familiares. Revista Brasileira de Agropecuária Sustentável, v.6, n.4, p.51-60, 2016. 